Бугайчук Костянтин Леонідович, кандидат юридичний наук, доцент, провідний науковий співробітник науково-дослідної лабораторії 3 проблем профілактики правопорушень та взаємодії 3 населенням, Харківський національний університет внутрішніх справ, м. Харків, e-mail: klbugaychuk@gmail.com

\title{
ПЕРСОНАЛЬНЕ НАВЧАЛЬНЕ СЕРЕДОВИЩЕ: ПЕРША СПРОБА ЗРОЗУМІТИ
}

\begin{abstract}
Анотація
Актуальність матеріалу, викладеного у статті, зумовлена потребами аналізу сучасних підходів до проведення навчального процесу, у тому числі з використанням можливостей мережі Інтернет. Останнім часом за кордоном особливу увагу дослідників привертає «теорія конективізму», яка пов'язана 3 розповсюдженням соціальних сервісів (сервісів web 2.0), а також питання щодо сутності персонального навчального середовища - Personal Learning Environment. Автором проаналізований термін web 2.0, досліджений його вплив на виникнення конективізму і формування персонального навчального середовища. На підставі дослідження праць авторів теорії конективізму і їх послідовників, визначений зміст поняття «персональне навчальне середовище» $\mathrm{i}$ його складові, а також сформована власна точка зору на сутність цього явища.
\end{abstract}

Ключові слова: персональне навчальне середовище, конективізм, web 2.0.

Постановка проблеми. Сучасний розвиток мережі Інтернет зумовлює виникнення принципово нових підходів до процесу навчання. Усе частіше процес передавання інформації здійснюється за допомогою так званих «соціальних сервісів» або сервісів web 2.0. Розвиток використання web 2.0. у повсякденному житті все частіше спонукає дослідників до вивчення проблем і переваг їх використання у навчальному процесі.

Ще у 2005 році канадський дослідник Стефан Доунс (Stephen Downes) висловив думку про виникнення нового покоління електронного навчання E-learning 2.0, яке безпосередньо пов'язане з поширенням використання web 2.0. Зокрема, дослідник зазначає, що: 
- $\quad$ виростає нове покоління людей, які використовують Інтернет на новому рівні (цифрові аборигени). Ці люди народилися, коли Інтернет уже існував, вони сприймають його як природну якість життя і вони звикли бути в мережі;

- $\quad$ нове покоління поводиться з фотографіями, відео і звуком так само, як і 3 текстом;

• вони працюють 3 великою кількістю джерел одночасно й потребують постійного зв’ язку і реакції на свої дії з боку інших осіб;

- вони готові створювати свої власні джерела інформації і переробляти існуючі мережеві джерела [1].

Розвиваючи свої ідеї, Стефан Доунс і Джордж Сименс (George Siemens) запропонували нову концепцію (теорію) навчання - конективізм. Основні його положення мають такий вигляд:

- навчання - це процес створення мережі;

- вузлами можуть бути зовнішні сутності, які ми можемо використовувати для формування мережі (люди, організації, бібліотеки, веб-сайти, книги, журнали, бази даних, або будь-яке інше джерело інформації);

- акт навчання полягає у створенні зовнішньої мережі вузлів, які ми підключаємо у формі джерел інформації і знань;

- навчання, що відбувається в нашій голові, $є$ формуванням внутрішньої нейронної мережі [2].

Розвиток ідей конективізму привів до виникнення поняття «персональне навчальне середовище». Проте проблеми його структури і змісту все ще залишаються поза увагою вітчизняних дослідників.

Аналіз основних досліджень. У 2010 році Дж. Сіменс і С. Доунс провели відкритий дистанційний курс «Personal Learning Environments Networks and Knowledge» - PLENK 2010, в основі якого була проблема висвітлення побудови персонального навчального середовища його структури й особливостей [3].

На пострадянському просторі слід відзначити праці Є.Д. Патаракіна, В. М. Кухаренка, С. Х. Васильченка, Ю. В. Еельмаа [4-9].

Однак на теперішній час дослідження цих категорій не набуло системного змісту і характеризується фрагментарністю підходів, зокрема, вітчизняні автори не 
розглядають поняття «середовище» стосовно окремого індивіда 3 позицій конективізму, а звідси зникає дослідження терміну «персональний».

Метою статті є визначення поняття персонального навчального середовища, дослідження його складових з точки зору конективізму і використання інструментів web 2.0.

Викладення основного матеріалу. Сучасне дистанційне навчання безпосередньо пов’язане з розвитком мережі Інтернет. Більша частина дистанційного навчального процесу переноситься в он-лайн. Отже, треба пам'ятати, що виникнення поняття «персональне навчальне середовище», як уже зазначалося, безпосередньо пов’язано другим поколінням Вебу (web 2.0) і концепцією (теорією) конективізму. Спираючись на вищезазначене, ми спробуємо окреслити основні риси останніх.

Що ж таке web 2.0? Термін «web 2.0» прийнято пов’язувати із статтею Тіма O’Рейлі «What Is Web 2.0» [10]. Він визначає його як методику проектування систем, які стають кращими завдяки тому, що ними користуються багато людей. Свої ідеї Тім O’Рейлі продовжує у статті «Web 2.0: 5 років потому»: «Головне наше розуміння мережі як платформи не значить, що ми пропонуємо використовувати старі програми у мережі, а означає створення продуктів, які стають кращими завдяки тому, що ними користується багато людей. Ефект роботи у мережі це не тільки залучення великої кількості користувачів, а й навчання користувачів один в одного» [11].

«Веб», як скорочене позначення WWW (World Wide Web), нині знайоме більшості Інтернет-користувачів як синонім понять «Мережа» й «Інтернет», проте, не можна говорити, що Веб тотожний Інтернету. Інтернет - явище фізичне (розшифровується як Interconnected Networks (3'єднані мережі) і є об'єднаними комп’ ютерними мережами, а Веб - це глобальний інформаційний простір, заснований на фізичній інфраструктурі Інтернету [4].

Пояснюючи суть web 2.0, Тім О’Рейлі наводить його порівняння iз web 1.0 (табл. 1).

Таблиця 1

\begin{tabular}{|r|l|l|}
\hline Web 1.0 & & Web 2.0 \\
\hline DoubleClick & $-->$ & Google AdSense \\
\hline Ofoto & $-->$ & Flickr \\
\hline Akamai & $-->$ & BitTorrent \\
\hline mp3.com & $-->$ & Napster \\
\hline
\end{tabular}




\begin{tabular}{|r|c|l|}
\hline Britannica Online & $-->$ & Wikipedia \\
\hline personal websites & $-->$ & blogging \\
\hline evite & $-->$ & upcoming.org and EVDB \\
\hline domain name speculation & $-->$ & search engine optimization \\
\hline page views & $-->$ & cost per click \\
\hline screen scraping & $-->$ & web services \\
\hline publishing & $-->$ & participation \\
\hline content management systems & $-->$ & wikis \\
\hline directories (taxonomy) & $-->$ & tagging ("folksonomy") \\
\hline stickiness & $-->$ & syndication \\
\hline
\end{tabular}

Отже, можна сказати, що web 2.0 - це філософія розвитку інформаційного простору мережі Інтернет. Основним джерелом створення, обробки i розповсюдження інформації є користувачі Інтернету, які розвивають інформаційний простір. Web 2.0 характеризується тим, що користувачі взаємодіють між собою завдяки відповідним інструментам, вони створюють інформацію, обмінюються нею, роблять їі спільну оцінку. Ці інструменти й отримали назву «соціальні сервіси».

Web 1.0 характеризувався наявністю в мережі Інтернет здебільшого статичних сайтів, якими керував адміністратор і завдяки яким користувач міг отримати певну інформацію, а інколи й завантажити іiі. Користувачі мали можливість залишати коментарі на форумах, але їх спільна активність була значно нижчою, ніж під час використання інструментів web 2.0. Отже, основними особливостями сервісів web 2.0. $\epsilon$ :

- велика кількість користувачів;

- $\quad$ контент мережі - це продукт активності користувачів сервісів web 2.0;

- сервіси web 2.0. постійно вдосконалюються, у тому числі й за участю користувачів. Тобто ви не встановлюєте на комп'ютер нову програму, а просто відкриваєте сторінку з оновленим сервісом;

- для використання сервісів web 2.0. потрібен комп'ютер 3 доступом в Інтернет і браузер. Звідси випливає висновок, що сервіс web 2.0. не може існувати на комп’ютері, не підключеному до Інтернету [12].

Розвиток web 2.0 принципово змінив інформаційну картину світу. Ці зміни можуть бути виражені так, як подано нижче.

1. Інформація стала поширюватися 3 неймовірною швидкістю. Її стало занадто забагато. Отже, з'явилася потреба у нових методах роботи з інформацією. 
2. Як уже зазначалося, виростає нове покоління людей, які використовують Інтернет на новому рівні - як простір проживання. Ці люди обробляють декілька джерел одночасно, створюють спільноти, однаково добре працюють з різними видами інформації (фото, відео, текст).

3. Сучасну людину вже не задовольняє односторонній механізм передавання інформації - вона прагне сама отримувати інформацію з різних джерел, створювати, відбирати та оцінювати її з власної точки зору.

4. Інформація не є беззаперечною. У чистому вигляді вона не має цінності - ¥іi цінність для себе визначає сама людина. «Авторитет» викладача, дії якого спрямовані тільки на передавання інформації, інколи не спрацьовує. Часто можна зустріти такі висловлювання викладачів: «Я передаю знання», але з нашої точки зору ця думка не $є$ зовсім правильною, оскільки викладачем передається певна інформація, яка згодом трансформується в знання - адекватне віддзеркалення зовнішнього і внутрішнього світу у свідомості людини у формі уявлень, понять, думок, теорій. Тобто знання - це форма існування і систематизації результатів пізнавальної діяльності людини.

5. На перший план у житті людини висувається пошук оптимальних методів отримання, обробки та передавання інформації.

Трансформація інформаційного простору мережі Інтернет поставила на перший план запитання: «Чи повинен змінюватися процес навчання в епоху розвитку нових технологій, якщо так, то як?», «Що нам зможуть дати соціальні сервіси і мережа Інтернет?».

У 2005 році виник напрям, або як його визначають автори, «Теорія навчання в цифрову епоху», яка отримала назву «конективізм».

Ключове положення конективізму - знання розподілено по мережах зв’ язків (network of connections), i тому навчання полягає в можливості конструювати ці зв'язки і проходити по них. Знання присутнє у зв'язках. Знання створюється в результаті дій і досвіду. Тому в конективізмі немає «передавання знань», «створення знань» (making knowledge), «побудови знань» (building knowledge) [13].

Щоб об’єкти вважалися з'єднаними, властивість одного об'єкта має привести до іншого або також стати його властивістю. Знання, яке випливає з таких з'єднань, вважається з'єднальним знанням (connective knowledge) [14, с. 16]. 
Зв’язки (connections) формуються природно через процес асоціацій, а не «конструюються» навмисно. Тому в конективізмі навчання схоже на зростання чи розвиток особистості. Це передбачає педагогіку, яка, по-перше, намагається описати «успішні» мережі, які характеризуються різноманітністю, автономністю, відкритістю i мають зв'язки (connectivity), і по-друге, намагається описати практики, які ведуть до таких мереж - моделювання і демонстрація з боку вчителя і практика з рефлексією 3 боку учня [13].

Для більш повного уявлення принципів конективізму доцільно узагальнити положення публікацій його засновників Дж. Сіменса і Ст. Доунса $[2,14,15]$.

Навчання - процес, який відбувається в невизначеному, туманному і мінливому середовищі, у якому постійно йдуть зрушення основоположних елементів. Цей процес не може перебувати повністю під контролем особистості. Навчання може підтримуватися ззовні і полягає в поєднанні інформаційних джерел. Це об'єднання інформаційних вузлів дозволяє нам підніматися на вищий рівень розуміння.

Навчання - це процес створення мережі. Вузлами можуть бути зовнішні сутності, які ми здатні використовувати для формування мережі: люди, організації, бібліотеки, веб-сайти, книги, журнали, бази даних або будь-яке інше джерело інформації. Акт навчання полягає у створенні зовнішньої мережі вузлів, які ми підключаємо у формі джерел інформації і знань.

Принципи конективізму:

- навчання i знання вимагають розмаїтості підходів і можливості вибору оптимального підходу;

- навчання - це процес формування мережі й підключення спеціалізованих вузлів і джерел інформації;

- знання можуть існувати поза людиною, технології допомагають нам у навчанні. Знання знаходиться в мережі;

- навчання і пізнання відбуваються постійно - це завжди процес і ніколи стан;

- ключова навичка сьогодення - здатність бачити сенс і встановлювати зв'язки між галузями знань, концепціями й ідеями;

- навчання - це процес прийняття рішень; 
- крізь призму мінливої реальності нам постійно доводиться обирати, чому вчитися, правильний вибір нині може виявитися хибним вибором завтра, під впливом того, що змінилися умови, у яких приймалося рішення.

Вихідною точкою для конективізму є особистість. Особисте знання становить мережу, яка підтримує розвиток організації, яка, у свою чергу, підтримує розвиток мережі і через розвиток мережі - навчання окремих учасників. Навчання відбувається у спільнотах, де навчальною практикою $є$ участь у житті спільноти. Навчання діяльності відбувається в процесі спілкування членів спільноти. Це спілкування в епоху web 2.0 складається не тільки зі слів, а й із зображень, мультимедія і багато чого іншого. Таке спілкування формує багате розмаїття динамічних i взаємопов'язаних ресурсів, які створюються не тільки експертами, але й усіма членами спільноти.

Найточніше, на нашу думку, ідею конективізму втілює такий вислів Стівена Доунса: «Все, що ми вивчаємо, та все, що ми знаємо.- це зв’язки, які ми формуємо між нейронами в результаті свого досвіду. Наш мозок складається зі 100 мільярдів нейронів, які формують 100 трильйонів зв’язків. Саме ці зв’язки і складають все, що ми знаємо та все, що ми уявляємо. I хоча зручно говорити, що наші знання та переконання складаються 3 понять та концепцій, які ми набуваємо та зберігаємо, більш точно та педагогічно говорити про навчання, як про формування зв' язків» [15].

3 принципів конективізму, які знайшли відображення у поняттях «вузол», «зв’язок», «мережа» і вагомої ролі сервісів web 2.0. У їх формуванні виник термін «персональне навчальне середовище».

Роботи російських і українських дослідників В. М. Кухаренка, Є. Д. Патаракіна i спеціалістів порталу Smart education дають нам таку структуру персонального навчального середовища (навчального простору, середовища навчання).

Персональне навчальне середовище (ПНС) - термін, який з'явився кілька років тому в західній літературі. До мінімального складу персонального навчального середовища, на думку західних колег, має входити twitter, ning, blog, igoogle (netvibes), reader RSS, delicious (diigo), wiki. ПНС - це не тільки комфортне середовище для виконання діяльності, але й засіб створення персональної навчальної мережі, такої мережі, де ми можемо взаємодіяти не тільки 3 нашими колегами, 
наприклад, учасниками співтовариства ning або списку розсилання, але i ï партнерами по спільній діяльності [5].

За останні п’ять років широко почав використовуватися термін «персональне навчальне середовище» (ПНС) і супутній йому термін «персональна навчальна мережа». Перший термін означає ті соціальні сервіси, які використовує особа для організації своєї роботи. Використовуючи ПНС, користувач створює свою персональну мережу, вузлами якої можуть бути люди, інформаційні матеріали мережі, інформаційні матеріали, створені користувачем ПНС. Деякою мірою, відносно студента ПНС виконує функції LMS [6].

Персональне навчальне середовище - це сукупність ресурсів, потрібних людині для того, щоб знайти відповіді на різноманітні питання, створити потрібний контекст для навчання і проілюструвати досліджувані процеси. Отже, персональне середовище навчання - це не конкретний додаток або служба, а особливий підхід до реалізації навчання [16].

Загальні принципи використання мережевих сервісів роблять помітний вплив на звичні форми організації навчального процесу. Під впливом нових засобів відбувається перехід від портфоліо до особистого навчального простору, який може бути організований на базі цілої низки соціальних сервісів. 3 технічної точки зору дуже важливо, щоб засоби, які підтримують формування особистого навчального простору, підтримували відкритий характер збережених даних і дозволяли іншим програмам обробляти й використовувати ці дані. Якщо ці засоби не мають таких можливостей, то його майбутнє як середовища для особистого навчального простору має вкрай сумнівний вигляд $[7,8]$.

Аналізуючи дослідження вищезазначених авторів, можна виділити три підходи до визначення персонального навчального середовища:

- персональне навчальне середовище - це соціальні сервіси, які використовує особа для організації своєї роботи;

- персональне навчальне середовище формується за допомогою соціальних сервісів;

- персональне навчальне середовище є особливим підходом до навчання.

Такі ж розходження існують і в працях зарубіжних дослідників. 
Перші кроки щодо визначення сутності і структури персонального навчального середовища у 2005 році зробив Скот Вілсон. Він називав цю концепцію «майбутнє віртуальне навчальне середовище» [17]. Згодом у 2006 році він сформулював такі ідеї персонального навчального середовища, як такого явища, що змінить традиційну освітню систему:

- треба сконцентруватися на тому, щоб координувати зв’язки між службами і користувачами, а не об'єднувати інструменти в межах відповідної інформації (контексту). Потрібно поширювати кількість інструментів, які виробляють різні компанії, не прив’язуючись до одного виробника. Вілсон зазначає, що це більш сумісно з компетентнісним підходом до навчання й дозволяє об'єднати свій досвід у рамках оточуючого середовища, включаючи освіту, роботу та приватне життя;

- будь-який користувач повинен аналізувати інформацією, створювати іiі i використовувати 3 метою задоволення своїх потреб. Персональне навчальне середовище дозволяє поширювати інформацію без обмеження середовищем якоїсь системи (наприклад, навчального закладу);

- персональне навчальне середовище в перспективі зробить уніфікацію платформ користування інструментами і приведе їх до спільного стандарту;

- на відміну від віртуального навчального середовища, персональне навчальне середовище спрямоване на спільне використання і роботу над ресурсами;

- персональне навчальне середовище дозволяє фільтрувати інформацію в межах відповідного контексту й організовувати взаємодію між людьми і їх групами;

- персональне навчальне середовище більш точно реалізує концепцію неформального навчання протягом усього життя [18].

Словник конективізму дає такі визначення: «Персональне навчальне середовище - це ярлик, який визначає відповідний індивідуальний зв'язок». «Персональна навчальна мережа - багато 3 нас є учасниками кількох навчальних спільнот, ось ці спільноти і створюють персональну навчальну мережу. Кожна спільнота є вузлом мережі» [19].

Джордж Сіменс висловлюється про персональне навчальне середовище з таких позицій: «Воно (середовище) не є структурним об' єктом, програмою або системою управління навчанням. За своєю сутністю - це набір інструментів, які пов’язані концепцією відкритості, здатності до взаємодії та управління 3 боку учня. 
Персональне навчальне середовище складається 3 двох елементів: інструменти та концептуальні поняття, які говорять, як і чому ми вибираємо окремі частини. Персональне навчальне середовище - це об'єкт поняття. Проблема в тому, що ми намагаємося обговорювати персональне навчальне середовище так, як би воно було виключно об’ єктом на кшталт LMS або CMS. Але якщо ці середовища існують, то вони дуже персоналізовані. Моє середовище може дуже відрізнятися від середовища колеги і складатися з дуже різних наборів інструментів» [20].

Мішель Мартін вказує на те, що персональне навчальне середовище - це не тільки інструменти web 2.0, але й люди, газети, журнали, книги, відвідування конференцій, спілкування між людьми в реальності [21].

Американські спеціалісти асоціації «Educause» визначають персональне навчальне середовище як інструменти, спільноти та послуги, які складають освітні платформи учнів з метою спрямування власного навчання і досягнення освітніх цілей. Персональне навчальне середовище - результат розвитку web 2.0 i його впливу на освітній процес [22]. Також вони зазначають, що термін «персональне навчальне середовище» охоплює весь набір ресурсів, які використовує учень, щоб відповісти на запитання, проілюструвати процеси і забезпечити пошук й обробку інформації. Персональне навчальне середовище - це зміни традиційної «історичної» моделі навчання. Подібної думки дотримується Сандра Шаферт: «... це набір соціальних інструментів, які зібрав учень з метою задоволення відповідних потреб» [23].

Підсумовуючи аналіз праць зарубіжних і вітчизняних учених і практиків у галузі використання в навчальному процесі web 2.0, конективізму i визначення сутності персонального навчального середовища, маємо зробити деякі висновки й узагальнення.

1. Трансформація інформаційного простору мережі Інтернет та виникнення сервісів web 2.0 (соціальних сервісів) зумовлюють потребу переглянути традиційні підходи до процесу навчання.

2. Концепція (теорія) конективізму описує нам трансформацію традиційної моделі навчання в цифрову епоху. Процес навчання вимагає не тільки професійної, а й інформативної компетентності як учня (студента), так і викладача.

3. Сучасне навчання потребує адекватних способів роботи 3 величезним потоком інформації: ii отриманням, узагальненням, фільтрацією та новим 
створенням. Важливими в сучасному навчальному процесі стають способи встановлення зв’ язків між різними носіями інформації. До речі, в юридичній практиці досі існує вислів «Усе законодавство знати не обов’ язково, потрібно знати, де знайти необхідне».

4. Процес навчання стає більш особисто-орієнтовним, де центральною фігурою є особистість учня (студента), а роль викладача зводиться до визначення основних орієнтирів у потоці інформації. Однобічне передавання інформації в навчальному процесі вже не актуальне. Стиль життя учнів зумовлює те, що вони прагнуть спілкуватися, створювати інформацію або окремі навчальні ресурси.

5. Застосування сервісів web 2.0 і поширення ідей конективізму привели до появи терміну «персональне навчальне середовище».

6. Однакового підходу до визначення поняття «персональне навчальне середовище» досі немає. Наукова спільнота, як і засновники теорії конективізму, знаходяться в пошуку оптимальної моделі персонального навчального середовища.

7. Основні підходи, що сформувалися до поняття і структури персонального навчального середовища, можна сформулювати так:

- це ті соціальні сервіси, які використовує користувач для організації своєї роботи (з метою задоволення освітніх потреб);

- це не тільки інструменти web 2.0, але й люди, газети, журнали, книги, відвідування конференцій, спілкування між людьми в реальності, усе, що використовує людина для навчання;

- персональне середовище навчання - це не конкретна програма або служба, а особливий підхід до реалізації навчання, у тому числі з використанням сервісів web 2.0 .

Своє власне ставлення до цього явища, напевно, слід визначити 3 використанням понять «інформація», «інформаційний простір» та «інформаційне середовище». Інформаційний простір не рівнозначний інформаційному середовищу: існуючи в одному і тому ж інформаційному просторі, людина може переходити 3 одного інформаційного середовища в інше. Людина може одночасно перебувати в різних інформаційних середовищах. Однією 3 особливостей інформаційного середовища є те, що будь-яке інформаційне середовище надає можливість отримання необхідних для нього даних, відомостей, гіпотез, теорій тощо. 
Тому персональне навчальне середовище - це скоріше власне інформаційне середовище, яке будує навколо себе людина, 3 метою задоволення власних навчальних потреб (досягнення відповідних навчальних цілей), а інструменти web 2.0, у цьому аспекті, виступають лише одним із допоміжних засобів організації власного інформаційного середовища, адже багато інформації останнім часом переміщується саме до мережі Інтернет, а як уже зазначалося, web 2.0 без Інтернету не існує. Слово «персональне», перш за все, означає те, що навчальні цілі в кожної людини свої власні «персональні», отже, й інформаційне середовище відносно навчальних цілей - теж буде персональним.

Звичайно, ця позиція може бути помилковою, але як можна побачити 3 назви статті, це тільки перша спроба зрозуміти. Проте, якщо ця позиція на сьогоднішній день правильна, завтра вона може змінитися відповідно до одного 3 принципів конективізму: «правильний вибір сьогодні може виявитися хибним вибором завтра, тому що змінилися умови, в яких приймалося рішення».

Проведений нами аналіз дозволяє окреслити перспективні напрями подальших досліджень у цій галузі: поняття персональної навчальної мережі і iї співвідношення 3 персональним навчальним середовищем, соціальні інструменти як засіб формування персонального навчального середовища.

\section{Список використаних джерел}

1. Downes Stephen E-learning 2.0 [Електронний ресурс] /S. Downes. - Режим доступу : http://elearnmag.acm.org/featured.cfm?aid=1104968.

2. Siemens George Connectivism: A Learning Theory for the Digital Age [Електронний pecypc] /G. Siemens. - Режим доступу : http://www.itdl.org/Journal/Jan_05/article01.htm.

3. Personal Learning Environments Networks and Knowledge 2010 [Електронний pecypc]. - Режим доступу : http://connect.downes.ca/index.html

4. Ээльмаа Ю. В. Образовательные возможности Веб 2.0. Веб 2.0-сервисы Интернета - новые формы коллективного педагогического взаимодействия [Електронний ресурс] / В. Ю. Ээльмаа // Использование Интернет-технологий в современном образовательном процессе. Часть II. Новые возможности в обучении. СПб. : РЦОКОиИТ, 2008. - С. 63 - 80. - Режим доступу до журн. : http://rcokoit.ru/dld/metodsupport/web20.pdf. 
5. Кухаренко В. М. Персональная учебная среда [Електронний ресурс] / В. М. Кухаренко. - $\quad$ Режим доступу : learning.blogspot.com/2011_03_01_archive.html.

6. Кухаренко В. М. Создание персональной учебной среды [Електронний pecypc] / В. М. Кухаренко. - Режим доступу : http://el-ukraine.wikispaces.com/1.1.

7. Патаракин Е. Д. Открытые сервисы для построения личного учебного пространства [Електронний ресурс] / Е. Д. Патаракин // Материалы XV Всероссийской научно-методической конференции «Телематика 2008» (23-26 червня 2008 p. Санкт-Петербург). - Режим доступу до журн. : www.ict.edu.ru/vconf/files/8629.pdf.

8. Патаракин E. Д. Построение учебной среды из множества личных «кирпичиков» [Електронний ресурс] / Е. Д. Патаракин //Высшее образование в России. - 2008. - № 8. - С. 59 - 65. - Режим доступу до журн. : www.ispu.ru/system/files/HiScool-c59-64_08-2008.pdf.

9. Васильченко С. Х. Персональная образовательная среда как комплексное средство оптимизации учебного процесса на основе информационных технологий [Електронний pecypc] / С. Х. Васильченко. - Режим доступу : http://confa.narod.ru/Vasilshenko.pdf.

10. O'Reilly Tim What Is Web 2.0: Design Patterns and Business Models for the Next Generation of Software [Електронний pecypc] / T. O'Reilly. - Режим доступу : http://oreilly.com/pub/a/web2/archive/what-is-web-20.html?page=1.

11. O'Reilly Tim Web 2.0: Five Years On [Електронний pecypc] / T. O'Reilly. Режим доступу : http://www.web2summit.com/web2009/public/schedule/detail/10194.

12. 10 definitions of Web 2.0 and their shortcomings [Електронний ресурс]. Режим доступу : http://twopointouch.com/2006/08/17/10-definitions-of-web-20-and-theirshortcomings.

13. Online Connectivism Conference: Forum [Електронний ресурс]. - Режим доступу : http://ltc.umanitoba.ca/moodle/mod/forum/discuss.php?d=12).

14. Siemens George Knowing Knowledge [Електронний pecypc] /G. Siemens. Режим доступу : http://www.elearnspace.org/KnowingKnowledge_LowRes.pdf.

15. Downes Stephen Connectivism and Connective Knowledge [Електронний pecypc] /S. Downes. - Режим доступу : http://www.downes.ca/post/54540. 
16. Персональная среда обучения - PLE [Електронний ресурс]. - Режим доступу : http://www.smart-edu.com/index.php/distantsionnoe-obuchenie/personalnayasreda-obucheniya-ple.html.

17. Wilson, Scott Future VLE - The Visual Version [Електронний ресурс] / S. Wilson. Режим доступу: http://www.cetis.ac.uk/members/scott/blogview?entry=20050125170206.

18. Personal Learning Environments: Challenging the dominant design of educational systems [Електронний pecypc]. http://ple.elg.ca/course/moodle/mod/wiki/view.php?id=60\&page=Week+1.

19. Connectivism glossary [Електронний pecypc]. - Режим доступу : http://en.wikiversity.org/wiki/Connectivism_glossary.

20. Siemens George PLEs - I Acronym, Therefore I Exist [Електронний ресурс] / G. Siemens. - Режим доступу : http://www.elearnspace.org/blog/2007/04/15/ples-iacronym-therefore-i-exist/.

21. Martin Michele M. Supporting Personal Learning Environments:A Definition of a PLE [Електронний ресурс] / M. M. Martin. - Режим доступу : http://michelemartin.typepad.com/thebambooprojectblog/2007/08/supporting-pe-1.html.

22. 7 Things you should know about PLE's [Електронний ресурс]. - Режим доступу : http://net.educause.edu/ir/library/pdf/ELI7049.pdf.

23. Schaffert Sandra, Hilzensauer Wolf Personal Learning Environments: Seven crucial aspects / S. Schaffert, W. Hilzensauer [Електронний ресурс]. - Режим доступу : www.elearningeuropa.info/mt/node/2680.

\section{ПЕРСОНАЛЬНАЯ УЧЕБНАЯ СРЕДА: ПЕРВАЯ ПОПЫТКА ПОНЯТЬ}

Бугайчук Константин Леонидович, кандидат юридических наук, доцент, ведущий научный сотрудник научно-исследовательской лаборатории проблем профилактики правонарушений и взаимодействия с населением, Харьковский национальный университет внутренних дел, г. Харьков, e-mail: klbugaychuk@gmail.com

\section{Аннотация}

Актуальность материала, изложенного в статье, обусловлена потребностями анализа современных подходов к проведению учебного процесса, в том числе с использованием возможностей сети Интернет. В последнее время за границей особое внимание исследователей привлекает «теория коннективизма», которая связана с 
распространением социальных сервисов (сервисов web 2.0), а также вопрос о сущности персональной учебной среды - Personal Learning Environment. Автором проанализирован термин web 2.0, исследовано его влияние на возникновение коннективизма и формирование персональной учебной среды. На основании исследования трудов авторов теории коннективизма и их последователей, определено содержание понятия «персональная учебная среда» и ее составляющие, а также сформирована собственная точка зрения на сущность этого явления.

Ключевые слова: Персональная учебная среда, коннективизм, web 2.0.

\section{PERSONAL LEARNING ENVIRONMENT: THE FIRST ATTEMPT TO UNDERSTAND}

Konstantin L. Bugaychuk, PhD, docent, Senior Researcher of Research Laboratory on crime prevention and interaction with the population, Kharkov National University of Internal Affairs, Kharkov, e-mail: klbugaychuk@gmail.com

\section{Resume}

Relevance of the material set forth in article stems from a need analysis of contemporary approaches to the learning process, including using the possibilities of the Internet. Recently, on the west attracts attention of researchers' theory of connectivism which is related to the proliferation of social services (services of web 2.0), as well as questions about the nature of a personal learning environment. The author analyzed the term web 2.0, research and its impact on the formation of connectivism and personal learning environment. The study author's works connectivism theory and their followers, determined the content of the concept of «personal learning environment» and its components, and formed its own views on the nature of this phenomenon.

Keywords: personal learning environment, connectivism, web 2.0.

Матеріал надійшов до редакції 07.10.2011 р. 